\title{
Harmonisation of Chalk and Cheese
}

\author{
Philip Davenport
}

(Solicitor of the Supreme Court of NSW, NSW Building Disputes Tribunal and Senior Lecturer, Faculty of the Built Environment, University of NSW)

\begin{abstract}
This is a response to Towards Harmonisation of the Construction Industry Security of Payment Legislation: A consideration of the success afforded by the East and West Coast Models in Australia by Jeremy Coggins, Robert Fenwick Elliott and Matthew Bell. Towards Harmonisation is based upon the false premise that the objectives of the East Coast and West Coast models are the same. They are chalk and cheese. Each serves a valuable purpose. Each jurisdiction needs both models. A model for a dual process incorporating both the East Coast and the West Coast models will be found in Davenport (2007).
\end{abstract}

\section{Introduction}

As an example of the so called East Coast model, the Building and Construction Industry Security of Payment Act 1999 NSW will be used. All the adjudication Acts in Australia, except those of Western Australia and the Northern Territory, are modelled on the NSW Act. As an example of the West Coast model, the Construction Contracts Act 2004 WA will be used.

Under the NSW Act, the role of the adjudicator is akin to that of a certifier such as the traditional superintendent. Under the WA Act, the role of the adjudicator is akin to that of an arbitrator. When enacted, the NSW Act was unique. No similar legislation existed anywhere. On the other hand, the WA Act follows a time honoured model similar to arbitration. It is because the East Coast model departs so radically from the existing processes of dispute resolution that so many people, including many in the judiciary, have found it such a difficult concept to grasp.

Under the NSW Act (s 21(1)(a)) the adjudicator determines the amount of the progress payment (if any)'. Under the WA Act (s 31) the adjudicator must dismiss the application or 'determine on the balance of probabilities whether the party to the payment dispute is liable to make a payment'.

The WA Act is concerned with any claim by any party for payment under or for breach of the construction contract. The NSW Act is only concerned with a claim by the party who carried out the work (or provided the goods or services) for a progress payment under the construction contract.

Under s 3(1) of the NSW Act provides:

The object of this Act is to ensure that any person who undertakes to carry out construction work (or who undertakes to supply related goods and services) under a construction contract is entitled to receive and able to recover progress payments in relation to the carrying out of that work and the supplying of those goods and services.

In NSW, adjudication is only one of the means by which that objective is achieved. Part 2 of the NSW Act creates a right to progress payments even when the construction contract does not provide for progress payments. Part 3 of the Act provides mechanisms to assist the 
claimant to recover progress payments much more expeditiously than by suing in court. A claimant can sue in court or, if the contract so provides, initiate arbitration to prove and recover progress payments. But claimants invariably prefer the mechanisms provided by Part 3 of the Act.

By contrast, Section 31 of the WA Act provides:

The object of an adjudication of a payment dispute is to determine the dispute fairly and as quickly, informally and inexpensively as possible.

The respective Acts serve their respective objectives. In NSW, it is an entitlement and ability to receive progress payments for carrying out work. In WA it is a mechanism for resolving all payment disputes. There is not a common objective as the Authors of Towards Harmonisation claim.

The Acts serve different purposes and there is need for a dual scheme of adjudication which incorporates both models. The Authors of Towards Harmonisation say that the key question at this stage is how a uniform national approach to security of payment regulation might be achieved. The answer is a dual scheme of adjudication that incorporates both the entitlement and ability to receive progress payments for carrying out work (as incorporated in the East Coast model) and a mechanism for resolving other payment disputes (as incorporated in the West Coast model).

A blend of chalk and cheese would be unpalatable, but separately each serves a useful purpose. A blend of the East Coast and the West Coast models will not work but a dual scheme incorporating both will work. WA is the poorer for not having compulsory rapid adjudication for progress claims (the East Coast model) and NSW is poorer for not having adjudication for other claims (the West Coast model). A dual scheme is described in Davenport (2007).

\section{Historical Background}

There is a long history of legislation in the United Kingdom dating from about 1464 known as the Truck Acts which were designed to ensure that employers paid employees promptly without deduction or set off. That legislation is now reflected in the Fair Work Act 2009 Cth which provides in $\mathrm{s} 323(1)$ that at least monthly an employer must pay an employee in full except for specific deductions permitted by s 324 . There was no similar legislative protection for contractors who were not employees. For 200 years the gap was filled in building and construction contracts by the provision of an architect, engineer or superintendent to act as certifier. The certifier is bound to independently certify the amount of progress payments due to the contractor. The contractor could obtain summary judgment for the certified amount just as under the East Coast model a claimant can obtain summary judgment for the adjudicated amount. Examples are Merrit Cairns Constructions v Wulguru Heights (1995) 12 BCL 293 and Blue Chip v Concrete Constructions (1996) 13 BCL 31.

In Chambers $v$ Goldthorpe [1901] 1 KB 624 it was held that the certifier was not liable for negligence in certifying. To reflect the independent status of the certifier the term 'quasiarbitrator' was used. While the certifier acted in good faith and independently, the contractor had a measure of protection against the principal who might be inclined to unjustifiably withhold payment. Then, 73 years later in Sutcliffe $v$ Thackrah [1974] AC 727, Goldthorpe was overruled and the certifier was held liable to the principal for negligently over-certifying progress payments. This caused considerable consternation to certifiers. They became very concerned about their independence and liability. The problem was compounded by Pacific Associates v Baxter [1988] 1 QB 993 when it was held that the contractor could not sue the independent certifier for undercertifying. The independent certifier virtually ceased to exist. The East Coast model, in effect, restores the pre 1974 situation and goes further. It provides

Davenport, P (2010) 'Harmonisation of Chalk and Cheese', Australasian Journal of Construction Economics and Building, 10 (3) $36-50$ 
for a truly independent certifier (the adjudicator) whenever there is a dispute over progress payments and it provides the certifier who acts in good faith with statutory immunity for negligence in certifying.

\section{Comparisons}

The East Coast model recognises the particular vulnerability of the party who carries out the construction work or provides related goods or services. In his second reading speech introducing the bill for the NSW Act, the Minister Mr. lemma said:

It is all too frequently the case that small contractors - such as bricklayers, carpenters, electricians and plumbers - are not paid for their work. Many of them cannot survive financially when that occurs, with severe consequences for themselves and their families. The Government is determined to rid the industry of such totally unacceptable practices.

In the Annual Report $2009-2010^{1}$ of the Building and Construction Industry Payments Agency of Queensland, referring the East Coast model Building and Construction Industry Payments Act 2004 Qld the General Manager says:

The Act was developed specifically to assist subcontractors who have struggled with payment issues for decades. Subcontractors lodged 602 of the 887 adjudication applications. The value of their claims was $\$ 109.4$ million

All too often, when it comes time for payment, the recipient of the work, goods or services does not pay. Sometimes a reason is provided. Often no reason is provided. The approach in the East Coast model is that if after a warning that the payment claim is made under the Act, the respondent fails to provide a reason for withholding payment, the claimant is entitled to elect between suing for payment of the claimed amount or having the payment claim adjudicated. In the latter event, the claimant must give the respondent another opportunity to provide a reason for withholding payment. If the respondent still provides no reason, the respondent is precluded from raising any reason in the adjudication.

Under the NSW Act, the claimant knows all the reasons, if any, that the respondent is entitled to raise for withholding the progress payment (or any part) before the claimant makes an election to go to adjudication. Compare the WA Act (s 27) where the respondent does not have to provide reasons for withholding payment until 14 days after being served with the adjudication application.

When a contractor is not paid on time, the common law did not give the contractor the right to suspend work. Both the NSW Act and the WA Act seek to redress this unfairness. The difference is that the NSW Act2 gives the contractor the right to suspend when payment is not made on time and the respondent has provided no reason for withholding payment. By contrast, when the respondent fails to pay the adjudicated amount, even if the respondent provides no reason, the claimant has no right under the Act to suspend work until after an adjudication 3 . This severely disadvantages the claimant.

Under the NSW Act, the respondent can only set off against progress payments amounts which the respondent has agreed (in the construction contract or subsequently) can be set off. Under the WA Act the respondent can raise counterclaims and have them adjudicated. A claimant in NSW who initiates an adjudication for a progress payment may be found not to be entitled to any payment and may have to pay the adjudicator's fees but the claimant will

\footnotetext{
${ }^{1}$ The report can be found at www.bcipa.qld.gov.au.

2 Sections 15(2)(b) and 27.

${ }^{3}$ Section 42 of the WA Act.
}

Davenport, P (2010) 'Harmonisation of Chalk and Cheese', Australasian Journal of Construction Economics and Building, 10 (3) $36-50$ 
not, by reason of going to adjudication, be liable to pay moneys to the respondent. In WA, going to adjudication for a progress payment is a risky process.

The time it takes a contractor to be paid for work is most important. Here the NSW Act provides a much speedier process but limited to progress payments. Take for example, a small contractor seeking a progress payment of $\$ 50,000$ under a simple contract with no provision for progress payments. The contractor serves a payment claim under the Act. If, within 10 business days, the contractor is not paid, the contractor gives the respondent notice of the contractor's intention to go adjudication. The respondent has 5 business days to give a reason for withholding payment. The claimant can then initiate an adjudication and have a determination of the entitlement, if any, to a progress payment within a maximum of 10 business days. The whole process takes approximately 20 to 30 business days.

At [2.1] of their paper the Authors say:

The East Coast model Acts provide a detailed statutory payments regime, overriding any inconsistent contractual provisions ... Conversely, the West Coast model Acts largely preserve (rather than override) the parties' contractual interim payment regimes.

The East Coast model does not override any fair contractual interim payment regime. The East Coast model is designed to override unfair contractual payment regimes and to provide a fair entitlement to progress payments where the contract fails to do so. The WA Act preserves unfair contractual payment regimes.

The Authors point out that the East Cost model only allows payment claim to be made up the 'contractual stream'. The East Coast model is only concerned with progress payments. By definition, these can only be made up the 'contractual stream'. What would be ideal is a model which provides separately for progress claims and for other claims. Neither the East Coast model nor the West Coast model does this.

At [2.4] of their paper the Authors say:

Few in the industry would seriously advocate that the present disjointed situation ought to continue; rather there have been increasing calls - echoing those of the Cole Royal Commission nearly a decade ago - to forge a uniform national approach to security of payment.

Should those States with the East Coast model wind back the protection which it provides to contractors and suppliers of goods and services and adopt the West Coast model? In September 2010 the Services, Technology \& Administration Department, NSW called for comments on a discussion paper ${ }^{4}$ on proposals to amend the NSW Act. Also in September 2010 the Queensland Government and the Queensland Building Services Authority issued a discussion paper ${ }^{5}$ inviting submissions on changes to the Queensland Act. A number of responses to the discussion papers advocate the adoption of a dual process to extend adjudication to other than progress payments. At the time of writing, the Writer has seen many of the responses but none seen by the Writer advocates replacing the East Coast model with the West Coast model. The Queensland Building and Construction Industry Payments Agency proposes publishing responses.

Should WA extend to contractors and suppliers the protection afforded by the East Coast model and wind back the existing right of both parties to have other money claims adjudicated? The Authors do not suggest that WA should provide the additional protection

\footnotetext{
${ }^{4}$ The discussion paper can be down loaded at www.services.nsw.gov.au.

${ }^{5}$ The discussion paper can be down loaded at www.bsa.qld.gov.au.
}

Davenport, P (2010) 'Harmonisation of Chalk and Cheese', Australasian Journal of Construction Economics and Building, 10 (3) $36-50$ 
(given by the East Coast model) to contractors with respect to progress payments. Both models provide benefits to sections of the construction industry. The answer is not to attempt to wind back any protections but to extend to the whole of the Australian construction industry the benefits of both models.

\section{Key Success Parameters}

In Section 3 of Towards Harmonisation under the heading Key Success Parameters the statistics cited show that the number of adjudication applications in WA on a population basis is about one fifth of that in Queensland. In Queensland only one party can make an adjudication application and then the application can only be in respect of a progress payment. If in Queensland both parties could make the range of money claims that can be made in WA, the number of adjudications in Queensland would almost certainly increase considerably. The Authors say that in WA the total value of payment claims in 2008/2009 was approximately $\$ 36$ million. In Queensland it was $\$ 223.9$ million according to the Building and Construction Industry Payment Agency (2010). About that time, the Writer adjudicated a single Queensland payment claim for $\$ 60$ million. The result does not show up in statistics because the parties requested that the decision not be published.

Under the heading Key Success Parameters the Authors say that to draw conclusions as to overall longer term legislative success based solely upon data indicating a significant uptake of statutory adjudication would be imprudent and misleading. They say:

It is proposed that such longer term success is predicated upon continued satisfaction of all stakeholders in the construction industry with the legislation's payment and adjudication schemes. Therefore, it is argued that there are several parameters which must be considered in assessing the success of the legislation in meeting its objective of achieving sustained improvement of cash flow throughout the construction industry.

The Authors identify the parameters as including:

- levels of justice afforded by the statutory scheme;

- the consequential costs of the legislative scheme to the construction industry both in terms of administrative and legal burden generated; and

- the impact of the legislation (positive or negative) on the relationship between the contracting parties.

Try telling that to the subcontractor who has not been paid for the work, goods or services which the subcontractor has supplied to the respondent. The subcontractor will respond along the lines, 'Get real. You are living in cloudland. All I want is to be paid and paid quickly'. The Queensland Building and Construction Industry Payments Agency (2010) shows that the overwhelming majority of claims submitted to adjudication were for amounts of less that $\$ 40,000$. In his second reading speech on 12 November 2002 introducing the Building and Construction Industry Security of Payment Amendment Bill the NSW Minister for Public Works and Services, Mr. Iemma, said:

The main purpose of the Act is to ensure that any person who carries out construction work or provides related goods or services, is able to promptly recover progress payments. The Government wanted to stamp out the practice of developers and contractors delaying payment to subcontractors and suppliers by ignoring progress claims, raising spurious reasons for not paying or simply delaying payment.

So far as the East Coast model is concerned, the key success parameter is whether the legislation assists subcontractors and contractors who carry out construction work (or provide related goods or services) to promptly recover progress payments. Hundreds of

Davenport, P (2010) 'Harmonisation of Chalk and Cheese', Australasian Journal of Construction Economics and Building, 10 (3) $36-50$ 
times, the Writer has seen first hand the spurious reasons which respondents raise to avoid paying for the work goods or services they have received. The process under the East Coast model is quick and efficient. The parties usually use lawyers for the larger claims but countless small contractors have successfully had their claims adjudicated without any legal assistance. Making a payment claim under the Act and lodging an adjudication application is a far less daunting prospect that issuing a summons and proving a case in court. A very valuable advantage for both parties is that they do not have to take time off work or give staff time off work to attend court. Adjudications are conducted in writing.

An important measure of the success of the East Coast model is identified in the Queensland Government and the Queensland Building Services Authority $(2010$, p6) as follows:

There is a view that the greatest benefit of the BCIPA [the Queensland Act] is the way in which it facilitates parties to payment disputes to resolve their disputes without referral to a formal adjudication or other court process. Industry stakeholders advise that in comparison to the actual number of adjudication applications lodged, many more matters are resolved through negotiation between the parties.

Through service of a payment claim under the BCIPA, the respondent is made aware:

- of the full details of the claim so they are in a position to readily understand the case the claimant is advancing for payment and therefore be in a position to possibly negotiate with the claimant a suitable outcome; and

- that the claimant is prepared to enforce their rights to payment through rapid adjudication process established by the BCIPA.

Industry stakeholders indicate that the BCIPA has in many cases resulted in respondents who in the past may have conducted their business so as to inappropriately delay/reduce payments to contractors and suppliers from being [un]able to continue this practice. This is because the subject respondents are aware that they cannot delay the adjudication process and if they fail to make a payment without justification they may be subject to an enforceable adjudication decision handed down against them.

On the other hand, claimants appear to generally accept that they will have to address legitimate reasons for the respondent declining to pay the full amount they claimed under a payment schedule.

The Authors say:

It is proposed that such longer term success is predicated upon continued satisfaction of all stakeholders in the construction industry with the legislation's payment and adjudication scheme.

Nothing will satisfy all stakeholders. The longer term success of the East Coast model is not predicated upon continued satisfaction of all stakeholders in the contraction industry. It is deliberately aimed at assisting only those who carry out construction work or provide related goods or services. It will forever remain unsatisfactory to the very large section of the construction industry that stands to benefit by delaying payment to subcontractors and suppliers by ignoring progress claims, raising spurious reasons for not paying or simply delaying payment.

Only Pollyanna could believe that any scheme that is aimed at stamping out 'the practice of developers and contractors delaying payment to subcontractors and suppliers by ignoring progress claims, raising spurious reasons for not paying or simply delaying payment' could

Davenport, P (2010) 'Harmonisation of Chalk and Cheese', Australasian Journal of Construction Economics and Building, 10 (3) $36-50$ 
meet the 'continued satisfaction of all stakeholders in the construction industry with the legislation's payment and adjudication scheme'.

\section{Justice in Dispute Resolution}

Under the heading 'Justice in Dispute Resolution', the Author's say: A linchpin of all the legislation is the interim resolution of payment claim disputes via a
mandatory adjudication scheme.

Often there is no dispute. Often the recipient of work, goods or services (the respondent) simply does not pay. The claimant has the choice of going to court or adjudication. Where the respondent has provided no reason for withholding payment, the adjudicator under the East Coast model does not decide any dispute. The adjudicator simply certifies the amount of the progress payment to be made by the respondent, the due date for payment and the rate of interest. The reason for adjudication is to give the claimant a faster, less daunting and less costly method of recovering payment as quickly as possible. This is not a general 'dispute resolution' scheme.

The process under the East Coast model Acts does, as the Authors say at [2.1], 'provide a detailed statutory regime, overriding any inconsistent contractual provisions'. This is necessary in order 'to ensure that any person who carries out construction work or provides related goods or services, is able to promptly recover progress payments' which the Minister Mr. lemma said is the main purpose of the legislation. However, as the Authors say:

Conversely, the West Coast model Acts largely preserve (rather than override) the parties' contractual interim payment regimes.

The consequence is that in WA any person who carries out construction work or provides related goods or services, is at a disadvantage when it comes to promptly recovering progress payments. Is that 'justice'?

At [4] the Authors distinguish 'substantive justice' and 'procedural justice'. They say:

Substantive, or distributive, justice essentially refers to the fairness of the outcome produced by a decision process. Procedural justice refers to the justice of the processes or methods used to arrive at distributive justice.

The Authors say that the key differences between the East and West Coast models impact upon the measures for procedural and substantive justice afforded by each model. Firstly, they identify the requirement under the East Coast model for the payment claim to bear the endorsement that the claim is made under the Act as a potential barrier to procedural fairness. This does not make sense. If the claimant intends to make a payment claim under the Act it is only fair that the claimant should warn the respondent.

The Authors say that a contractor or supplier may deliberately refrain from endorsing its payment claim through fear of negative repercussions in its relationship with the principal. The Authors say:

This effectively denies such a contractor or supplier access to the dispute resolution process available under the Act.

That is not so. Whilst ever the contractor (or supplier) is satisfied with the contractual regime for progress payments and dispute resolution, the contractor does not need to use the statutory dispute resolution process. The option for access to the dispute resolution process

Davenport, P (2010) 'Harmonisation of Chalk and Cheese', Australasian Journal of Construction Economics and Building, 10 (3) $36-50$ 
available under the Act remains open for the contractor if the contractual regime breaks down. There cannot be said to be any denial of justice.

At [5.2] the Authors correctly point out that the East Coast model provides for recovery of progress payments only and can only be used by the contractor or supplier to recover payment from the person for whom the work was carried out or to whom the goods or services were supplied. They say:

Herein lies another potential barrier to procedural justice in the East Coast model, as the judiciary has allowed claimants to recover amounts for delay damages in adjudicated payment claims under the Act.

The four NSW Court of Appeal cases cited as authority for this proposition are all cases in which the construction contract provided an entitlement to have the delay damages included in the calculation of progress payments. The cases confirm that the Act does not provide an entitlement to a progress payment for damages except where and to the extent that the construction contract gives the contractor that entitlement. The Authors say:

This as Davenport puts it, creates an 'imbalance' as only one party is allowed to apply for adjudication of payment disputes regarding damages.

The Authors refer to the Writer's paper A proposal for a dual process of adjudication. What the Author proposed is that under a dual process respondents who are stupid enough to include provision for inclusion of delay costs in progress claims under their contracts should be protected against their own stupidity and all damages claims should be adjudicated under a process separate from that applying to progress claims for the value of work, goods or services. The Writer said at $\mathrm{p} 15$ of the paper:

The proposed dual process would retain the certification process for purely progress payment claims, ie for claims for the value of work, goods or services that have actually been provided, and to adopt the traditional process for other payment disputes. The dual process would continue the existing legislation for progress claims (redefined to exclude the broader interpretation sometimes adopted by the Courts) and would allow either party to have damages and debt claims adjudicated separately.

The 'certification process' identified by the Writer is essentially the East Coast model and the 'traditional process' is essentially the West Coast model. At pp 14-15 the Writer said:

The dual process would retain the objective of the certification process. In $s 3$ of the NSW Act it is 'to ensure that any person who undertakes to carry out construction work ... is entitled to receive, and is able to recover, progress payments in relation to the carrying out of that work'. But the Dual Process would also adopt the objective of the traditional process. In s.3 of the NZ Act it is to provide 'for the speedy resolution of disputes arising under a construction contract' and to provide 'remedies for the recovery of payments under a construction contract'. In the WA Act it is 'to provide a means for adjudicating payment disputes arising under construction contracts'.

The Authors say at [5.2]:

As claims for damages falling within the scope of the contract have the potential to be made by either contractual party, it would appear to be blatantly unfair to allow only one party the right to refer such claims to the Acts dispute resolution processes.

This is true. But if the contractual regime allows a contractor to include damages in a progress claim, the NSW Act does not override the parties' agreement, as unwise as it may be. The dual process advocated by the Writer would override that aspect (where it exists) of the contractual regime and allow equal rights to both parties when it comes to adjudication of claims for damages.

Davenport, P (2010) 'Harmonisation of Chalk and Cheese', Australasian Journal of Construction Economics and Building, 10 (3) $36-50$ 
At [5.3] the Authors say that where the respondent has not provided a reason for withholding payment, in adjudication under the East Coast model the respondent is disallowed from lodging an adjudication response. The Authors say that this effectively denies the respondent any voice during the adjudication. Bearing in mind that the adjudication is only of a payment on account, it is not unfair that the respondent who gives no reason for withholding payment before the adjudication application is made should be barred from thereafter raising a reason. The claimant has no opportunity to dispute or canvass a reason which was not included in the payment schedule. Before going to adjudication under the East Coast model, the claimant knows all the respondent's reasons for withholding payment. Conversely, under the West Coast model, the claimant commences the adjudication without knowing what reasons the respondent may raise in the adjudication.

There are countless instances where an adjudicator (including the Writer) has not allowed a progress payment or the whole of the claimed amount even when the respondent has elected not to make a submission or is barred from making a submission. In Brookhollow $v$ R\&R Consultants [2006] NSWSC 1 Palmer J at [62] said:

Because an adjudication determination can have drastic financial consequences, s.22(2) [of the NSW Act] requires the adjudicator to see that, even when the respondent does not participate, the process is not abused.

\section{At [5.3] the Authors say:}

Indeed $41 \%$ of adjudication applications in Queensland to date for the 2009/10 financial year have been made on the basis that the respondent has failed to serve a payment schedule on the claimant.

Before the claimant could take any of these claims to adjudication, the claimant had to give the respondent two opportunities to provide a reason for withholding payment and a warning that the claimant intends to have the payment claim adjudicated. Despite two opportunities the respondent has failed to provide any reason for withholding payment. Strictly speaking the adjudicator is not deciding a dispute between the parties. The adjudicator's role is to check that the processes required by the Act before an entitlement to a progress payment arises have been satisfied and to certify the amount, if any, of the progress payment to which the claimant is entitled.

The respondent is not locked out of the process. The respondent receives notice of the appointment of the adjudicator and a copy of the adjudication application. The respondent can contend in the adjudication or in court that the processes required by the Act have not been satisfied6. What the respondent cannot do is have yet another opportunity to raise reasons (for withholding payment) which the respondent should have raised before the adjudication commenced but elected not to raise. It is not very different to the court process. If a defendant fails to lodge a defence, the defendant cannot complain if the case is decided on the claimant's evidence.

At [5.3] the Authors say:

Failure to serve a payment schedule not only strips the respondent of any right to subsequently defend that payment claim, but it may also potentially result in a gross miscarriage of substantive justice or, at the very least, an outcome which is not perceived fair by the respondent.

It must be remembered that the respondent has been given two opportunities to provide a payment schedule setting out any reason for withholding payment and a warning that the

\footnotetext{
${ }^{6}$ Chase Oyster Bar v Hamo Industries [2010] NSWCA 190.
}

Davenport, P (2010) 'Harmonisation of Chalk and Cheese', Australasian Journal of Construction Economics and Building, 10 (3) $36-50$ 
claimant intends to have the progress payment adjudicated. How many opportunities should the respondent be given? How much longer should the claimant have to wait for payment? Why, if the respondent has chosen not to provide a reason for withholding payment, should the claimant have to pursue a more costly and time consuming process than the simple form of adjudication provided under the East Coast model? Prior to enactment of the East Coast model, it was the claimant who was denied justice in the circumstance where the respondent provided no reason for withholding payment. The claimant had to sue in the courts for the payment. The injustice arose from the cost and delay in pursuing that litigation and the fact that by the time to process was complete the respondent may be insolvent. It may be that the delay in recovering payment could bankrupt the claimant.

There is no potential for a gross miscarriage of substantive justice. If the respondent perceives that the outcome is unfair, there is nothing in the legislation to prevent the respondent from suing for return of the money.

The Authors say:

Even in circumstances where the respondent has duly served a payment schedule, it may only include in its adjudication response reasons for withholding payment which have previously been included in the payment schedule. Thus a respondent may be prevented from being able to present its full case to the adjudicator unless it has previously served a comprehensive payment schedule which covers all the issues it may wish to rely on subsequently.

The respondent is not prevented from presenting its full case to the adjudicator. The respondent is restricted from raising in the adjudication reasons of which claimant has not been given prior notice in the payment schedule. This is only fair. The claimant must be given a fair opportunity of deciding whether to contest the respondent's reasons and, if so, to do so in the adjudication application. The claimant is not entitled to raise new claims in the adjudication. The respondent is not entitled to raise new reasons for withholding payment.

The Authors point out that under the West Coast model there are no limitations as to the inclusion of reasons for withholding payment in a response to an adjudication application. This is a flaw in the West Coast model. The respondent can raise reasons for withholding payment that the claimant has never been informed of. The claimant has to elect whether to go to adjudication or not without knowing the case in response which the claimant may have to meet.

Here is an example. The respondent's reason for withholding payment may be that certain work is defective. If the claimant is made aware of this reason, the claimant may elect not to proceed to adjudication at that stage but to rectify the defect or get an expert report and perhaps pursue a payment claim at a later date. However, under the West Coast model the claimant may not be aware of the respondent's reason for withholding payment until after the adjudication commences. This is an unfair and inefficient process.

Referring to the East Coast model, the Authors say:

These highly restrictive provisions with regards to payment schedules and adjudication responses have a major impact upon consideration of procedural and substantive justice.

This is not how the parliaments of NSW, Queensland, Victoria, South Australia, Tasmania and the ACT see it. This is not how the courts see it. The 'highly restrictive provisions' apply equally to both parties. To ensure that the progress payment to which a party is entitled is decided promptly, in the adjudication the claimant is not entitled to raise additional claims and the respondent is not entitled to raise additional reasons but there is no restriction on

Davenport, P (2010) 'Harmonisation of Chalk and Cheese', Australasian Journal of Construction Economics and Building, 10 (3) $36-50$ 
either party providing any amount of submissions and material in support of the claims in the payment claim or the reasons for withholding payment in the payment schedule.

The Authors say:

It is difficult to conceive of any fair and respected dispute resolution process denying the right for one of the parties to put forward their arguments or, at the very least, to be heard. Indeed it is a fundamental right of most dispute resolution processes that both parties have the right to present their case. Lack of opportunity for the respondent to present its case, together with the consequent likelihood of a determination perceived as unjust by the respondent, would seem a recipe for respondent dissatisfaction with the dispute resolution processes provided by the East Coast model.

The East Coast model gives each party an equal opportunity to put forward its arguments on progress payments. There is no lack of opportunity for the respondent to present its case. The payment claim and the payment schedule are, in effect, pleadings just like a statement of claim and defence in litigation or arbitration. In litigation or arbitration a party is not entitled to present a case different to that on the pleadings. So too in adjudication under the East Coast model.

At [5.4] the Authors say that the East Coast model does not permit the parties any legal representation at conferences called by the adjudicator. This is a non issue. It is extremely rare for the adjudicators to call conferences. Despite adjudicating hundreds of claims over a decade, the Writer has never once called a conference. In the last 1,000 determinations under the East Coast model that the writer has perused, no adjudicator has held a conference.

At [5.4] the Authors point out that the West Coast model allows the adjudicator to determine his or her own adjudication procedure and to inform himself or herself in any way he or she thinks fit. The procedure under the East Coast model is spelt out so that the adjudication is quick and inexpensive and cannot be expanded beyond the determination of the progress payment due. To ensure an expeditious process and minimize costs, the adjudicator is not permitted to determine his or her own adjudication procedure and is not entitled to inform himself or herself in any way he or she thinks fit.

At [5.4] the Authors say that under the East Coast model the parties cannot agree upon the appointment of a particular individual as adjudicator. That is not true. When a dispute arises, it is always open to the parties to agree upon the authorised nominating authority [the ANA] to make the nomination of an agreed adjudicator. In fact they never agree and as a consequence the Act provides that the claimant should serve the adjudication application to the government authorised ANA of its choice.

At [5.4] the Authors point out that under the West Coast model, the parties to the construction contract may agree in the contract upon a registered adjudicator or prescribed appointer. As the Authors concede this provides an opportunity for a party with dominant bargaining power to unfairly influence the identity of the adjudicator at the time of contract formation and thereby erode substantive justice. That is a flaw in the West Coast model which does not exist in the East Coast model.

At [5.4] the Authors point out that all eight of the ANAs in WA are construction or professional bodies or associations. They say that six of the nine ANAs in NSW are construction or professional bodies or associations and three are private for profit companies. This may, in part, explain the slow uptake of adjudication in WA. Generally speaking, construction or professional bodies or associations bodies have not proven to be very efficient and enthusiastic ANAs or willing to incur the capital and running expenses and

Davenport, P (2010) 'Harmonisation of Chalk and Cheese', Australasian Journal of Construction Economics and Building, 10 (3) $36-50$ 
engage the staff to provide the registry services which adjudicators require if they are to be efficient and have a continuing flow of adjudication work. The ANA with which the most adjudication applications are lodged is Adjudicate Today Pty Ltd. Adjudicate Today has a full time staff of eight running a registry, assisting parties comply with the procedural provisions of the Act and assisting adjudicators on its panels. It operates in NSW, Victoria, Queensland, Tasmania and the ACT and has trained and accredited adjudicators in each of those jurisdictions. Adjudicate Today has gone to great lengths to provide separately for each jurisdiction information, flowcharts, templates and guidelines for payment claims, payment schedules, adjudication applications, adjudication responses and various notices ${ }^{7}$.

The Authors say:

Generally, the professional bodies and associations provide nomination/appointment services as part of their service to the profession they represent.

Therein lies a conflict of interest. An ANA should not treat nomination or appointment of an adjudicator as a service to any particular profession. An ANA should not see its statutory role as a part of its service to the profession it represents. Its statutory role should be seen as a completely separate and independent role.

The Authors note that all ANAs under the east Coast model and the West Coast model take a commission from the fee paid by the disputing parties to the adjudicator. They point out that the commission varies from ANA to ANA. They say:

This raises a question as to whether adjudication outcomes are in any way affected by a claimant's choice of a particular appointing body, and particularly whether there is any correlation between the level of commissions appropriated from adjudicators' fees by appointing bodies and substantive outcomes of adjudications. There appears to be little, if any, research into this question to date.

All adjudicators' decisions in Queensland are published on the web site of the Queensland Building and Construction Industry Payments Agency www.bcipa.qld.gov.au. In each case the ANA which nominated the adjudicator is identified. Anyone who wants to investigate the question of whether adjudication outcomes are in any way affected by a claimant's choice of a particular appointing body can do their own research.

Some claimants may perceive that the adjudication outcome may be influenced by the choice of a particular constructional or professional body or association as the ANA because that ANA is there to serve its members. Each ANA has a panel of potential adjudicators from whom it selects the adjudicator to determine an adjudication application. If an ANA has a very limited panel of potential adjudicators [who are known to the claimant] or a panel comprising one profession, the claimant might perceive a better outcome from that ANA. That is an argument for ANAs to be private companies with a large panel of adjudicators from all sections of the construction industry and related professions.

It is difficult to see how there could be any correlation between the level of commission paid by the adjudicator to the ANA and the outcome of the adjudication. Why would an adjudicator, on account of the amount of the service fee payable to the ANA, be inclined to favors one party over the other? It does not make sense. The amount of the service fee is quite independent of the outcome of the adjudication.

Constructional and professional bodies and associations are created for the benefit of shareholders or members. Their directors are no less likely to be influenced by the profit

\footnotetext{
${ }^{7}$ See www.adjudicate.com.au.
}

Davenport, P (2010) 'Harmonisation of Chalk and Cheese', Australasian Journal of Construction Economics and Building, 10 (3) $36-50$ 
incentive than the directors of any other company. In fact, it could be argued that because they are controlled and managed by people with interests in the particular profession or industry, they are less likely to be truly independent when selecting adjudicators. They are likely to appoint their own members and may be inclined to maximize the return to their appointees by minimizing the level of commission.

Any comparison of commissions must take into account the services provided by the ANA to adjudicators. Some provide no services whatsoever. Some provide only minimal services. Some are very efficient and provide all the services which an efficient registry would provide. The services provided by the best include an office in each jurisdiction for receipt of documents, delivery of documents to and from each State and service upon the adjudicator of legal process, secretarial services, training, continuing professional development courses, proof reading of decisions and service of decisions on the parties, collection of adjudications fees, submitting appearances and, most importantly, a buffer between parties and the adjudicator. Some parties to adjudication are so concerned about the money that they can be quite intimidating. It is one thing to deal with legal representatives. It is another to deal with parties face to face. Most parties to adjudication are not legally represented.

The 'service' which an adjudicator provides is greatly enhanced by the quality of the support services provided by the ANA. To have efficient back up and full registry services is imperative for efficient 'service'. Also, to be efficient, an adjudicator needs a regular flow of adjudication work. This can only be supplied by an ANA that actively advertises and promotes adjudication so that claimants see the potential benefits of adjudication and can readily ascertain the process and download forms. This costs money. There is no government assistance so adjudicators have to meet the cost unless they are members of an industry or professional organisation which subsidises the cost. That, in itself, could create a conflict of interest.

At $p 18$ the Authors refer to the 'ambush claim' but they rightly concede that it may equally occur under the West Coast model. A potential solution is not, as the Authors suggest, to limit the length of written submissions. The answer is to be found in the dual scheme of adjudication proposed by the Writer.

\section{Administrative and Legal Burdens}

Under the heading 'Administrative and Legal Burdens created by the Legislation', the Authors say at [6.1]:

The statutory system operated by the East Coast model inevitably creates extra administrative workload, above and beyond normal contract administration duties, for parties on a construction contract. This is not the case under the West Coast model, which allows primacy of the contractually agreed payment system.

The first example the Authors give of the alleged extra administrative load is that in a payment claim under the East Coast model the claimant must identify the work for which payment is claimed 'sufficiently to enable the respondent to understand the basis of the claim'. Surely this is only reasonable.

The progress payment is on account of the final contract price. The Authors refer to the 'Protectavale principle'. There is no such 'principle'. The requirements for a valid payment claim under the NSW Act are very simple. See s 13(1). It is easier to make a payment claim under the Act than to make a progress claim under any standard form contract. The Act does not impose any additional administrative or legal burden on the claimant.

The Authors say at 21:

Davenport, P (2010) 'Harmonisation of Chalk and Cheese', Australasian Journal of Construction Economics and Building, 10 (3) $36-50$ 
It is suggested that the requirement for the respondent to prepare a comprehensive payment schedules, in order to preserve its right to put forward the merits of its argument, is practicably too onerous. ...

It would be hard to exaggerate the importance and difficulty of providing payment schedules to every single payment claim that comes into an office. A typical head contractor will receive a large number of payment claims each month and it is extremely common for head contractors to fail to keep on top of the paperwork required by the legislation.

Under the East Coast model a claimant can only make one payment claim for each reference date. This is usually monthly but a contract can provide for less frequent intervals. It was extremely common for head contractors to fail to keep up on top of the paperwork. The consequence was that progress payments to subcontractors were not being made at the agreed time. That is why there was need for the NSW Act. Subcontractors should not be disadvantaged by the head contractor's failure to keep on top of their paperwork. The respondent only has to provide a payment schedule for those claims (for a payment on account) made under the Act which the respondent refuses to pay. The burden is no more onerous than the provision of the superintendent's payment certificate that is required under most standard forms of construction contract.

The Authors say:

Furthermore, if a respondent rejects a payment claim in a payment schedule, this does not prevent a tenacious claimant from making the same claim month after month.

There is some case law to the contrary but there is no need to go into that. The respondent can simply provide the same payment schedule each month or say in each payment schedule that the reasons for withholding payment are set out in the first payment schedule. The Authors are not correct when they say that the respondent must spell out all of its reasons on each occasion. Reasons previously given can be included by reference. In most instances the payment schedule is a very brief document.

\section{Volume of Litigation and Clarity of the Law}

Under this heading the Authors say at [6.3] that in the decade since the NSW Act commenced there have been 210 Supreme Court judgments and 41 Court of Appeal judgments in relation to issues concerning the Act. The Authors say that the majority of judgments represent attempts by the respondent to set aside an adjudicator's determination. All but two of the attempts to set aside the adjudicators determination were instigated by respondents. This is not surprising. Only respondents have to pay the adjudicated amount. The amount of litigation and number of times that the NSW Supreme Court itself has been found to have decided in error is concerning. The Authors say at 24:

Such diversity in the amount of litigation generated by the NSW and WA legislation may, perhaps, be reflective of respondents' level of dissatisfaction, and consequent lack of willingness to accept the adjudicator's decision, with the substantive and procedural justice afforded by each of the two models.

It is not that complicated. The amount of litigation in NSW is simply indicative of the lengths to which respondents will go to avoid paying progress payments on account. It is indicative of the difficulty of achieving the objective of the NSW Act, namely, 'to ensure that any person who undertakes to carry out construction work (or who undertakes to supply related goods and services) under a construction contract is entitled to receive and able to recover progress payments in relation to the carrying out of that work and the supplying of those goods and services'. It is indicative of what a lottery litigation is and how it can be used to delay or avoid payment.

Davenport, P (2010) 'Harmonisation of Chalk and Cheese', Australasian Journal of Construction Economics and Building, 10 (3) $36-50$ 
At $p 25$ the Authors say:

Additionally, the significant body of NSW case law generated by the Act may be reflective of a lack of clarity with respect to the legislative drafting leaving many issues to be interpreted and given certainty by the judiciary.

The significant body of case law reflects the failure of the judiciary to give certainty to issues of interpretation of the legislation. The NSW Act provides a novel scheme so unlike arbitration or litigation that judges have had problems accepting it ${ }^{8}$. The conflicting judicial interpretations encourage challenges. If the judiciary ever gives certainty, the amount of litigation will drop substantially. The concerns of the NSW and Queensland Governments with the level litigation are reflected in their respective September 2009 discussion papers referred to above.

In their conclusion the Authors say:

To be sustainable, the procedure and outcome of a dispute resolution process need to satisfy the stakeholders in order to achieve efficiency (in terms of time and cost) and finality.

All stakeholders will never be satisfied the procedure and outcome of any dispute resolution process whether it is court, arbitration or adjudication and whether the adjudication is the East Coast model or the West Coast model. There is nothing to suggest that the East Coast model is not sustainable. It has been around for more than a decade. It has been copied in all States other than W.A. It has been copied in Singapore. It has enabled thousands of contractors, subcontractors and suppliers to recover payment much more quickly and at less cost than payment could have been recovered, if at all, without the legislation. There is no reason for abandoning the East Coast model but there is scope for adjudication of other money claims as the West Coast model allows.

\section{References}

Davenport, P. (2007) \#115 Australian Construction Law Newsletter 12

Building and Construction Industry Payments Agency, Annual Report 2009-2010 available at www.bcipa.qld.gov.au

\footnotetext{
${ }^{8}$ A classic example is with respect to repeat claims. In John Goss v Leighton Contractors [2006] NSWSC 798 the adjudicator determined that where a previous adjudicator had determined that the claimant was not entitled to a particular progress claim for alleged delay costs the doctrine of issue estoppel applied. The NSW Supreme Court held otherwise and that the claimant was entitled to have the same claim adjudicated again. This gave rise to a flood of repeat claims where the claimant was dissatisfied with the determination in earlier adjudication. It was almost three years later that the NSW Court of Appeal found that the Supreme Court was wrong. See Dualcorp $v$ Remo Constructions [2009] NSWCA 69. This was not an example of any problem with the clarity of the legislation. It was purely an example of an error by the Supreme Court.
}

Davenport, P (2010) 'Harmonisation of Chalk and Cheese', Australasian Journal of Construction Economics and Building, 10 (3) $36-50$ 